\title{
A proteomic perspective on the changes in milk proteins due to high somatic cell count
}

\author{
L. Zhang, ${ }^{*}$ S. Boeren,† A. C. M. van Hooijdonk, ${ }^{*}$ J. M. Vervoort, † and K. A. Hettinga ${ }^{* 1}$ \\ *Dairy Science and Technology Group, and \\ †Laboratory of Biochemistry, Wageningen University, 6700EV, Wageningen, the Netherlands
}

\begin{abstract}
Although cows with subclinical mastitis have no difference in the appearance of their milk, milk composition and milk quality are altered because of the inflammation. To know the changes in milk quality with different somatic cell count (SCC) levels, 5 pooled bovine milk samples with SCC from $10^{5}$ to $10^{6}$ cells $/ \mathrm{mL}$ were analyzed qualitatively and quantitatively using both one-dimension sodium dodecyl sulfate PAGE and filter-aided sample preparation coupled with dimethyl labeling, both followed by liquid chromatography tandem mass spectrometry. Minor differences were found on the qualitative level in the proteome from milk with different SCC levels, whereas the concentration of milk proteins showed remarkable changes. Not only immunerelated proteins (cathelicidins, IGK protein, CD59 molecule, complement regulatory protein, lactadherin), but also proteins with other biological functions (e.g., lipid metabolism: platelet glycoprotein 4, butyrophilin subfamily 1 member A1, perilipin-2) were significantly different in milk from cows with high SCC level compared with low SCC level. The increased concentration of protease inhibitors in the milk with higher SCC levels may suggest a protective role in the mammary gland against protease activity. Prostaglandin-H2 Disomerase showed a linear relation with SCC, which was confirmed with an ELISA. However, the correlation coefficient was lower in individual cows compared with bulk milk. These results indicate that prostaglandin-H2 D-isomerase may be used as an indicator to evaluate bulk milk quality and thereby reduce the economic loss in the dairy industry. The results from this study reflect the biological phenomena occurring during subclinical mastitis and in addition provide a potential indicator for the detection of bulk milk with high SCC.
\end{abstract}

Key words: proteomics, mastitis, mammary gland, somatic cell count

Received December 23, 2014.

Accepted April 27, 2015.

${ }^{1}$ Corresponding author: kasper.hettinga@wur.nl

\section{INTRODUCTION}

Mastitis, an inflammation of the mammary gland, is one of the most devastating diseases affecting dairy cows, which results in changes of milk appearance, milk composition, and SCC (Forsbäck et al., 2010; Awale et al., 2012). A decrease in $\mathrm{CN}$ and whey protein concentrations has been reported to occur during mastitis (Hogarth et al., 2004). The lactose, sodium, and potassium contents were also found to be changed in concentration in milk from cows with mastitis due to leaky tight junctions (Hagiwara et al., 2003; LindmarkMånsson et al., 2006). Inflammation of the mammary gland during mastitis easily develops in response to infection and can lead to severe damage to the milk secretory tissue of the udder, resulting in a reduction in milk production and deteriorated milk quality (Hogarth et al., 2004). Mastitis is therefore considered as a major source of economic losses on dairy farms and a serious burden on the dairy producers.

Although milk from cows with subclinical mastitis does not have visible changes in the appearance, as mentioned above, changes in milk composition and high SCC do occur. Milk from quarters with subclinical mastitis showed elevated levels of sodium, chloride, albumin, lactate dehydrogenase activity, and immunoglobulins as well as reduced levels of $\alpha-\mathrm{LA}, \beta-\mathrm{LG}$, calcium, inorganic phosphorus, and potassium (Batavani et al., 2007). It also contributes to an average milk production loss of $470 \mathrm{~kg}$ per primiparous dairy cow and $740 \mathrm{~kg}$ per multiparous dairy cow during the full lactation with each unit increase in $\log _{10}(\mathrm{SCC})$ (Koldeweij et al., 1999). Thus, the greater the SCC increase, the greater the production loss. In addition, subclinical mastitis causes a similar reduction of reproductive performance as mastitis (Schrick et al., 2001). High SCC in milk has been considered as the only evidence that helps in the diagnosis of subclinical mastitis (Turk et al., 2012). Therefore, identifying new biomarkers for subclinical mastitis may help to develop an easy test aiming at predicting milk suitability for further milk processing. Consequently, it is interesting to study the differences of the milk proteome between healthy 
cows and cows with high SCC for understanding the variations of proteins expressed in milk from cows with subclinical mastitis. This may contribute to potential biomarker discovery for the detection of bovine subclinical mastitis.

Compared with the effect of subclinical mastitis, the effect of clinical mastitis has been studied much more widely. For instance, Yang et al. (2009) detected differently expressed proteins in the mammary gland from mastitis cows and healthy cows, such as hemoglobin, $\beta-\mathrm{CN}, \kappa-\mathrm{CN}$, and tryptophanyl-tRNA-synthetase, which all showed lower concentrations in milk from mastitis cows, whereas cytochrome $\mathrm{C}$ oxidase and annexin $\mathrm{V}$ showed higher abundance in milk from mastitis cows (Yang et al., 2009). Proteases, including plasmin, cathepsin B and D, elastase, and amino- and carboxypeptidases, were identified in bovine milk following infusion with lipoteichoic acid isolated from Staphylococcus aureus (Larsen et al., 2010). Low-abundant inflammation markers such as serotransferrin, fibrinogen $\beta$ chain, S100 calcium-binding protein A12, and the antimicrobial cathelicidins were shown to be present in relative high amounts in milk $12 \mathrm{~h}$ after infusion with Escherichia coli lipopolysaccharide (Hinz et al., 2012). Only few studies have been carried out on the milk proteome of cows with subclinical mastitis. Safi et al. (2009) found that acute phase proteins (haptoglobin and amyloid A) increased in milk from cows with subclinical mastitis (Safi et al., 2009). Serpin A3-1, vitronectin-like protein, and complement factor $\mathrm{H}$ were shown to be upregulated in milk from subclinicalmastitis cows in comparison with healthy cows (Turk et al., 2012).

The objective of the present study was to investigate the influence of high SCC (up to $10^{6}$ cells $/ \mathrm{mL}$ ) on the milk proteins in bovine milk by one-dimensional SDS-PAGE and also by filter-aided sample preparation (FASP) combined with dimethyl labeling, both followed by liquid chromatography tandem mass spectrometry (LC-MS/MS). Using shotgun proteomics techniques to determine variation in protein levels in milk from infected cows will increase our understanding of the influence of high SCC levels on the protein composition of milk, thereby providing potential biomarkers for detecting milk with a high SCC level.

\section{MATERIALS AND METHODS}

\section{Sample Collection}

A total of 100 cows were used in this study. Milk samples were a mixture from all 4 quarters of each cow. Five groups were made, consisting of pooled samples from 20 cows with similar SCC, which are SCC1 $\left(<10^{5}\right.$ cells $/ \mathrm{mL}) ; \operatorname{SCC} 2\left(2.25-2.75 \times 10^{5}\right.$ cells $\left./ \mathrm{mL}\right) ; \mathrm{SCC} 3$ $\left(4.8-5.3 \times 10^{5}\right.$ cells $\left./ \mathrm{mL}\right) ; \mathrm{SCC} 4\left(7-8 \times 10^{5}\right.$ cells $\left./ \mathrm{mL}\right)$; and SCC5 $\left(9.25-10.75 \times 10^{5}\right.$ cells $\left./ \mathrm{mL}\right)$. The sample with lowest SCC (SCC1) will be referred to as "low SCC." All other samples (SCC2-SCC5) represent samples with increased cell counts and will be referred to as "high SCC," because SCC $2.5 \times 10^{5}$ cells $/ \mathrm{mL}$ (SCC2) is considered the threshold for subclinical mastitis (Turk et al., 2012).

Sodium azide (0.02\% wt/wt) and bronopol $(0.0005 \%$ $\mathrm{wt} / \mathrm{wt}$ ) were added to prevent bacterial growth in these pooled milk samples supplied by Qlip (Dutch milk controlling station, Zutphen, the Netherlands). Several (28) individual samples with SCC ranging from $1 \times$ $10^{5}$ to $8.5 \times 10^{5}$ cells $/ \mathrm{mL}$ were also collected from Qlip for determining the relation between prostaglandin-H2 D-isomerase (PTGDS) and SCC in the milk serum of individual cows.

\section{Milk-Composition Analysis and Proteomics Technique}

Milk samples were analyzed for SCC, DM, protein, fat, and lactose contents by CombiFoss 5000 by Qlip. The proteomics methods used in this study are based on previous articles (Wisniewski et al., 2009; Hettinga et al., 2011; Lu et al., 2011).

Milk Serum Separation. To separate milk serum, pooled samples were centrifuged at 1,500 $\times g$ for $10 \mathrm{~min}$ at $10^{\circ} \mathrm{C}$ (Beckman Coulter AvantiJ-26 XP centrifuge, rotor JA-25.15, Brea, CA). The pellet was removed, and the obtained supernatant was transferred to the ultracentrifuge tubes followed by ultracentrifugation at $100,000 \times g$ for 90 min at $30^{\circ} \mathrm{C}$ (Beckman L-60, rotor $70 \mathrm{Ti}$, Beckman Coulter). After ultracentrifugation, samples were separated into 3 phases. Milk serum, in the middle layer, was separated and used for the proteomics sample preparation, as described below.

$\boldsymbol{S D S}-\boldsymbol{P A G E}$. Sodium dodecyl sulfate-PAGE was used to further separate milk proteins. Samples were subjected to one-dimensional SDS-PAGE using precast $12 \%$ Precise Protein Gels with HEPES buffer (Thermo Fisher Scientific Inc., Waltham, MA). The thawed protein samples were mixed 1:1 with $2 \times$ sample buffer (125 mM Tris-HCl (pH 6.8), 4\% SDS, $20 \%$ glycerol, $0.01 \%$ bromophenol blue in water); just before use, $5 \%$ $\beta$-mercaptoethanol was added, and the samples were heated for $5 \mathrm{~min}$ at $95^{\circ} \mathrm{C}$. Gels were loaded with approximately $30 \mu \mathrm{g}$ of protein per well. The gels were run for $45 \mathrm{~min}$ at $130 \mathrm{~V}$ and then fixed and stained with the Colloidal Blue Staining Kit (LC6025, Invitrogen, Carlsbad, CA) for $4 \mathrm{~h}$ and finally destained overnight in water. 
In-Gel Digestion. Except when stated otherwise, all $\mathrm{NH}_{4} \mathrm{HCO}_{3}$ (ABC, $\left.0.05 M\right)$ buffers used in this section were $\mathrm{pH}$ 8. After each step, the samples were sonicated for 1 min followed by centrifugation. For each sample, the gel lane was cut into 8 slices. Each slice was cut into pieces of maximum $1-\mathrm{mm}^{3}$ size using a scalpel and transferred to a low-binding microcentrifuge tube (0030 108.094, Eppendorf, Hamburg, Germany). The gel pieces were washed twice with water. The proteins were reduced by incubation in $0.05 M$ dithiothreitol for $1 \mathrm{~h}$ at $60^{\circ} \mathrm{C}$ followed by incubation in $0.1 \mathrm{M}$ iodoacetamide for $1 \mathrm{~h}$ at room temperature in the dark. After carboxamidomethylation, the gel pieces were washed 3 times with $0.05 \mathrm{MABC}$ buffer. The gel pieces were then frozen and thawed 3 times to increase the accessibility for trypsin. Next, the samples were rehydrated in $20 \mu \mathrm{L}$ of freshly prepared trypsin solution $(10 \mathrm{ng} / \mu \mathrm{L})$. Extra $0.05 M$ ABC buffer was added to completely cover the gel pieces before they were incubated overnight at room temperature. The next day, the basic supernatant of digest solution was transferred to a clean low-binding microcentrifuge tube. The gel pieces were extracted twice with $10 \mu \mathrm{L}$ of $5 \%$ trifluoroacetic acid in water and $10 \mu \mathrm{L}$ of $10 \%$ acetonitrile/1\% trifluoroacetic acid, respectively, with sonication after each extraction step. The supernatants after every sonication were added to the same low-binding microcentrifuge tube. Final pH of the peptide mixture was checked using $\mathrm{pH}$ paper.

$\boldsymbol{F A S P}$. Filter-aided sample preparation was used to digest milk proteins into peptides for identification and quantification. Milk serum samples $(20 \mu \mathrm{L})$ were diluted in $0.1 M$ Tris $/ \mathrm{HCl} \mathrm{pH} 8.0+4 \% \mathrm{SDS}+0.1$ $M$ dithiothreitol to get a $1 \mu \mathrm{g} / \mu \mathrm{L}$ protein solution. Samples were then incubated for $5 \mathrm{~min}$ at $95^{\circ} \mathrm{C}$ and then cooled down to room temperature, and $10 \mu \mathrm{L}$ of sample was directly added to a Pall $3 \mathrm{~K}$ omega filter (10-20 kDa cut off, OD003C34; Pall, Washington, NY) and centrifuged at $15,871 \times g$ for 1 min. A total of 100 $\mu \mathrm{L}$ of $8 M$ urea in $0.1 M$ Tris $/ \mathrm{HCl} \mathrm{pH} 8.0$ (UT) was added to the filter and centrifuged at $15,871 \times g$ for 30 min. A total of $100 \mu \mathrm{L}$ of $0.05 M$ iodoacetamide in UT was added and incubated for $10 \mathrm{~min}$ at room temperature and then centrifuged at $15,871 \times g$ for $30 \mathrm{~min}$ to alkylate cysteine residues within proteins. Another 3 centrifugations at $15,871 \times g$ for 30 min were carried out after adding 110, 120, and $130 \mu \mathrm{L}$ of UT, respectively, to remove remaining detergent. After that, 140 $\mu \mathrm{L}$ of $\mathrm{ABC}$ was added to the filter unit and centrifuged at $15,871 \times g$ for 30 min to provide an optimal $\mathrm{pH}$ for the enzymatic cleavage. Then, the filter was transferred to a new low-binding Eppendorf tube. A total of 100 $\mu \mathrm{L}$ of $\mathrm{ABC}$ containing $0.5 \mu \mathrm{g}$ of trypsin was added and centrifuged at $15,871 \times g$ for $30 \mathrm{~min}$ to collect peptides after $2 \mathrm{~h}$ of incubation at $45^{\circ} \mathrm{C}$. Finally, the filter was removed, and $3.5 \mu \mathrm{L}$ of $10 \%$ trifluoroacetic acid was added to adjust the $\mathrm{pH}$ value of the sample to around 2. These samples were ready for dimethyl labeling.

Dimethyl Labeling. To determine the precise changes in proteins from milk with low SCC and high SCC, dimethyl labeling was used. Milk sample with low SCC (SCC1) was labeled with the light reagent (the mix of $\mathrm{HCHO}$ and sodium cyanoborohydride) as reference, whereas milk samples with high SCC (SCC2, SCC3, SCC4, SCC5) were labeled with the heavy reagent [the mix of formaldehyde (DCDO) and sodium cynoborohydride]. The dimethyl labeling method was carried out using on-column dimethyl labeling according to (Boersema et al., 2009). Stage tips containing 2 mg of LiChroprep C18 (25- $\mu$ m particles; Merck Millipore, Amsterdam, the Netherlands) column material (C18+ Stage tip) columns were made in house. The $\mathrm{C} 18+$ Stage tip column was washed 3 times with $200 \mu \mathrm{L}$ of methanol. The column was conditioned with $100 \mu \mathrm{L}$ of $1 \mathrm{~mL} / \mathrm{L}$ formic acid in water $(\mathbf{H C O O H})$, and then samples were loaded on the C18+ Stage tip column. The column was washed with $100 \mu \mathrm{L}$ of $1 \mathrm{~mL} / \mathrm{L} \mathrm{HCOOH}$ and then slowly flushed with $100 \mu \mathrm{L}$ of labeling reagent $\left(0.2 \% \mathrm{CH}_{2} \mathrm{O}\right.$ or $\mathrm{CD}_{2} \mathrm{O}$ and $30 \mathrm{~m} M$ cyanoborohydride in $50 \mathrm{~m} M$ phosphate buffer $\mathrm{pH}$ 7.5) in about $10 \mathrm{~min}$. The column was washed again with $200 \mu \mathrm{L}$ of $1 \mathrm{~mL} / \mathrm{L}$ $\mathrm{HCOOH}$. Finally, the labeled peptides were eluted with $50 \mu \mathrm{L}$ of $70 \%$ acetonitrile $/ 30 \% 1 \mathrm{~mL} / \mathrm{L} \mathrm{HCOOH}$ from the $\mathrm{C} 18+$ Stage tip columns. The samples were then dried in a Speed-Vac (AG 22331, Eppendorf, Hamburg, Germany) at $35^{\circ} \mathrm{C}$ for 1.5 to $2 \mathrm{~h}$ until the volume of each sample decreased to $15 \mu \mathrm{L}$ or less. The pairs of light dimethyl label and heavy dimethyl label were then mixed up to $100 \mu \mathrm{L}$ by adding $1 \mathrm{~mL} / \mathrm{L} \mathrm{HCOOH}$. These samples were ready for analysis by LC-MS/MS.

$\boldsymbol{L} \boldsymbol{C}-\boldsymbol{M S} / \boldsymbol{M S}$. A total of $18 \mu \mathrm{L}$ of the trypsindigested milk fractions was injected on a $0.10 \times 30$ $\mathrm{mm}$ Magic C18AQ 200A $5 \mu \mathrm{m}$ beads (Michrom Bioresources Inc., Auburn, CA) preconcentration column (prepared in house) at a maximum pressure of 27,000 $\mathrm{kPa}$. Peptides were eluted from the preconcentration column onto a $0.10 \times 200 \mathrm{~mm}$ Prontosil 300-3-C18H analytical column (Prontosil, Bischoff, Germany) with an acetonitrile gradient at a flow of $0.5 \mu \mathrm{L} / \mathrm{min}$, using gradient elution from 9 to $34 \%$ acetonitrile in water with $0.5 \mathrm{vol} / \mathrm{vol} \%$ acetic acid in $50 \mathrm{~min}$. The column was washed using an increase in the percentage acetonitrile to $80 \%$ (with $20 \%$ water and $0.5 \mathrm{vol} / \mathrm{vol} \%$ acetic acid in the acetonitrile and the water) in $3 \mathrm{~min}$. Between the preconcentration and analytical columns, an electrospray potential of $3.5 \mathrm{kV}$ was applied directly to the eluent via a solid 0.5 -mm platina electrode fitted into a P777 Upchurch microcross (IDEX, Oak Harbor, WA). Full scan positive mode FTMS spectra 
were measured between $m / z 380$ and 1,400 on an LTQOrbitrap XL (Thermo Electron, San Jose, CA). The CID fragmented MS/MS scans of the 4 most abundant doubly and triply charged peaks in the FTMS scan were recorded in data-dependent mode in the linear trap (MS/MS threshold $=5.000)$.

Data Analysis. Each run with all MS/MS spectra obtained was analyzed with Maxquant1.3.0.5 with Andromeda search engine (Cox and Mann, 2008; Cox et al., 2011). Carboxamidomethylation of cysteines was set as a fixed modification (enzyme $=$ trypsin, maximally 2 missed cleavages, peptide tolerance $20 \mathrm{ppm}$, fragment ions tolerance $0.5 \mathrm{amu}$ ). Oxidation of methionine, Nterminal acetylation and deamidation of asparagine or glutamine were set as variable modifications for both identification and quantification. The bovine reference database for peptide and protein matching was downloaded from Uniprot (http://www.uniprot.org/) with reverse sequences generated by Maxquant. A set of 31 protein sequences of common contaminants was added including trypsin (P00760, bovine), trypsin (P00761, porcine), keratin K22E (P35908, human), keratin K1C9 (P35527, human), keratin K2C1 (P04264, human), and keratin K1C1 (P35527, human). A maximum of 2 missed cleavages were allowed and mass deviation of 0.5 Da was set as a limitation for MS/MS peaks and maximally $6 \mathrm{ppm}$ deviation on the peptide $\mathrm{m} / z$ during the main search. The false discovery rate was set to $1 \%$ on both peptide and protein levels. The length of peptides was set to be at least 6 amino acids. Finally, proteins were displayed based on minimally 2 distinct peptides of which at least one was unique.

Dimethyl labeling was based on doublets with dimethLys0 and dimethNter0 as light (L) and dimethLys4 and dimethNter4 as heavy (H). Razor peptides (peptides that are nonunique, which are assigned to the protein with the most other peptides) and unique peptides (peptides that are unique to one protein) were used for quantification. Normalized heavy:light $(\mathrm{H} / \mathrm{L})$ ratios calculated as the median of all dimethyllabeled peptide-pair ratios that belong to one protein were used for further statistical analysis. In each liquid chromatography-mass spectrometry run, peptide ratios were normalized, so that the median of their logarithms was zero, which corrects for unequal protein loading (Cox and Mann, 2008; Cox et al., 2011). Also, the intensity-based absolute quantification algorithm was used, which calculates absolute protein amounts as the sum of all peptide intensities divided by the number of theoretically observable tryptic peptides. The intensitybased absolute quantification value has been reported to have a good correlation with known absolute protein amounts over at least 4 orders of magnitude (Malmström et al., 2009; Schwanhausser et al., 2011).
The function of the identified proteins was checked in the UniProtKB database released April 2012 (http:// www.uniprot.org/). Gene Ontology enrichment analysis was done using DAVID bioinformatics Resources 6.7 (Dennis et al., 2003; http://david.abcc.ncifcrf.gov/). The significant analysis in the changes of milk composition was conducted by one-sample $t$-test in SPSS (Version 21, IBM Corp., Armonk, NY), which has been used in the significant analysis of microarraybased gene expression (Patterson et al., 2006). For the changes of individual proteins, a 2-fold change was used as the significant cut-off in this study, which has been reported in the previous milk proteomics studies done by FASP and dimethyl labeling (Lu et al., 2011, 2013). The linear correlation analysis between SCC and the relative concentration of milk proteins was performed in SPSS (Version 21, IBM Corp.).

\section{ELISA}

An ELISA was used to confirm the correlation between PTGDS and SCC that was found in the LCMS/MS analysis. The samples were diluted 5,000-fold aiming at the final concentration of PTGDS ranging from 93.75 to $6,000 \mathrm{pg} / \mathrm{mL}$. The concentration of PTGDS in the milk serum was detected in duplicates by the ELISA kit (bovine PTGDS, MBS942806) bought from EMELCA Bioscience Company (Breda, the Netherlands). The ELISA test, including creation of a standard curve, was performed according to the manufacturer's instructions. A 4-parameter logistic model, $y$ $=[d+(a-d)] /\left[1+(x / c)^{b}\right]$, was used for calibration by MasterPlex ReaderFit (Hitachi Solutions America Ltd., San Bruno, CA). The standard curve $y=2.69-2.65$ / $(1+x / 673.33)^{-1.41}\left(\mathrm{r}^{2}=0.988\right)$ was used to calculate the concentration of PTGDS in the samples based on the response value from the micro plate reader.

\section{RESULTS}

\section{Identification of the Milk Serum Proteome}

Table 1 shows the composition of the milk samples of the 5 groups (20 cows per group) with different SCC levels. No significant differences were found in milk composition among these 5 groups $(P>0.05)$. After proteomic analysis using one-dimensional SDS-PAGE combined with nanoLC-Orbitrap-MS/MS (Thermo Electron, San Jose, CA), a total of 273 proteins from the 5 pooled samples were identified (Supplemental Table S1; http://dx.doi.org/10.3168/jds.2014-9279). The number of identified proteins had minor differences (less than 10\%) between the groups. From the group with the lowest SCC to the group with the highest 


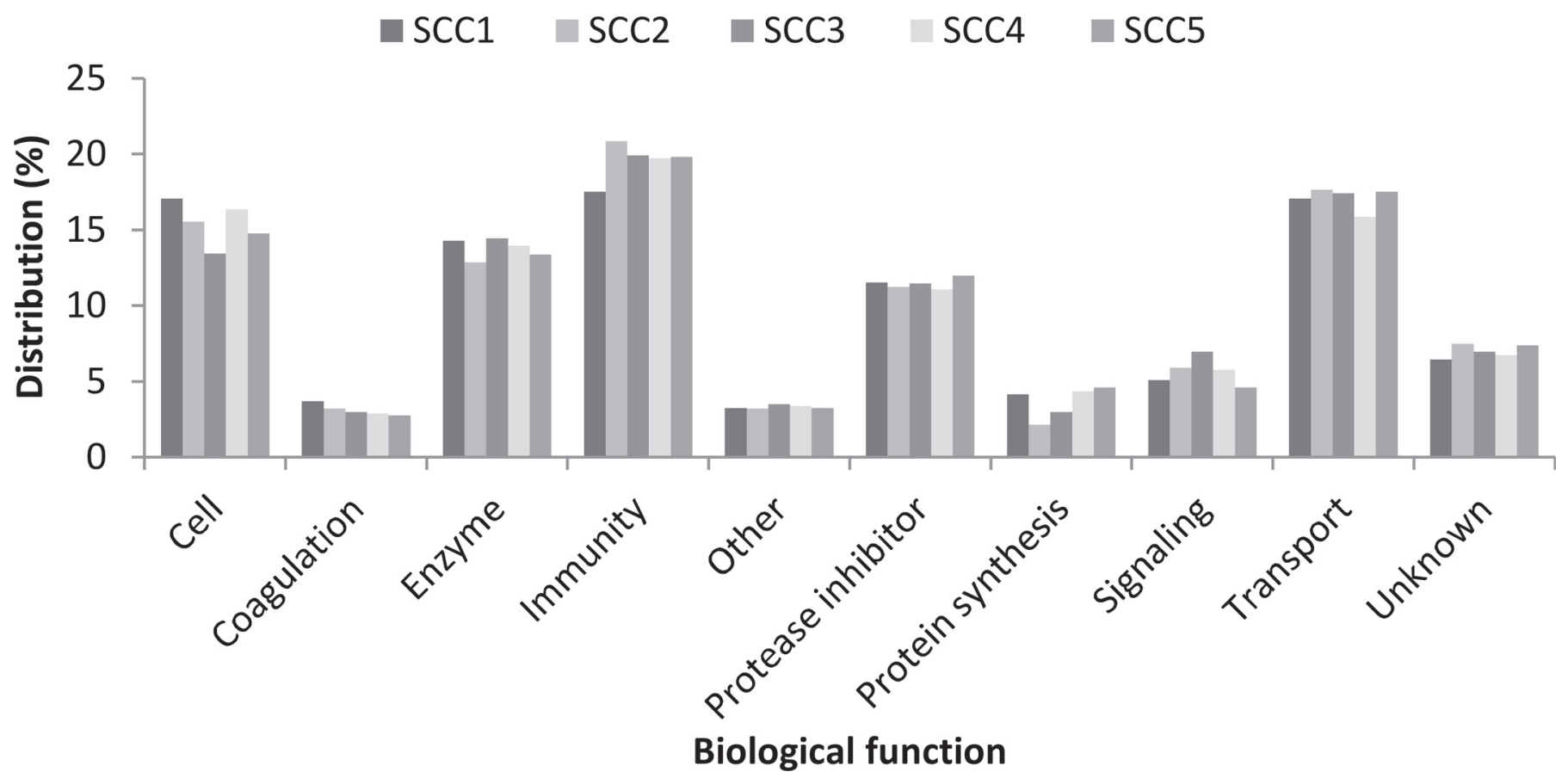

Figure 1. Functional ontology classification of proteins in bovine milk with different level of SCC $\left(\mathrm{SCC} 1=<10^{5}\right.$ cells $/ \mathrm{mL} ; \mathrm{SCC} 2=2.5 \times 10^{5}$ cells $/ \mathrm{mL} ; \mathrm{SCC} 3=4 \times 10^{5}$ cells $/ \mathrm{mL} ; \mathrm{SCC} 4=7.5 \times 10^{5}$ cells $/ \mathrm{mL} ; \mathrm{SCC} 5=10^{6}$ cells $\left./ \mathrm{mL}\right)$. Cell includes cell adhesion, cell mobility, cell growth, and cell apoptosis.

SCC, 217, 187, 201, 208, and 217 proteins were identified, respectively. The proteins identified were grouped based on their biological functions and subcellular locations according to Gene Ontology using DAVID (Dennis et al., 2003) as shown in Figure 1 and 2. Most of the proteins identified were linked to immunity, transport, cell functions (including cell adhesion, cell mobility, cell growth, and cell apoptosis), or enzymes. Based on the subcellular location, the 3 major groups, secreted, membrane, and cytoplasm, constituted more than $90 \%$ of the total proteins. Secreted was the dominant subcellular location and accounted for around $45 \%$ of the total proteins. Even though proteins originating from endoplasmic reticulum, Golgi, lysosome, and nucleus accounted for a very little part of identified proteins, they were present in all of these samples as shown in Figure 2. The number of identified proteins based on their biological functions and subcellular locations did not change with the increase of SCC.

\section{Quantification of the Milk Serum Proteome}

To know the influence of high SCC on the expression level of the milk proteome, FASP combined with dimethyl labeling, followed by nanoLC-Orbitrap-MS/ MS, was used for quantitative analysis. A total of 100 proteins were quantified (as shown in Supplemental Table S2; http://dx.doi.org/10.3168/jds.2014-9279). The biological functions and relative concentration of the 56 common proteins are shown in Table 2. A specific group of immune-related proteins, including all cathelicidins, PTGDS, Ig gamma-2 chain C region (IGHG2), and inter- $\alpha$-trypsin inhibitor heavy chain H4 (ITIH4),

Table 1. Composition of the milk samples with different level of SCC (SCC1 $=<10^{5}$ cells $/ \mathrm{mL}$; SCC2 $=2.5 \times$ $10^{5}$ cells $/ \mathrm{mL} ; \mathrm{SCC} 3=4 \times 10^{5}$ cells $/ \mathrm{mL} ; \mathrm{SCC} 4=7.5 \times 10^{5}$ cells $/ \mathrm{mL} ; \mathrm{SCC} 5=10^{6}$ cells $/ \mathrm{mL}$ )

\begin{tabular}{lrrrrrrr}
\hline & & & & & & \multicolumn{2}{c}{$\begin{array}{c}\text { One-sample test } \\
\text { (test value }=0)\end{array}$} \\
\cline { 5 - 8 } & & & & & & $\begin{array}{c}\text { Significance } \\
\text { (2-tailed) }\end{array}$ & $\begin{array}{c}\text { Mean } \\
\text { Milk }\end{array}$ \\
composition & SCC1 & SCC2 & SCC3 & SCC4 & SCC5 & \\
\hline DM (\%) & 13.8 & 13.46 & 13.24 & 13.42 & 13.22 & 0.943 & 0.008 \\
Protein (\%) & 3.72 & 3.65 & 3.91 & 3.68 & 3.54 & 1 & 0.000 \\
Fat (\%) & 4.42 & 4.48 & 4.24 & 4.52 & 4.46 & 1 & 0.000 \\
Lactose (\%) & 4.84 & 4.49 & 4.16 & 4.34 & 4.37 & 0.973 & 0.004 \\
\hline
\end{tabular}




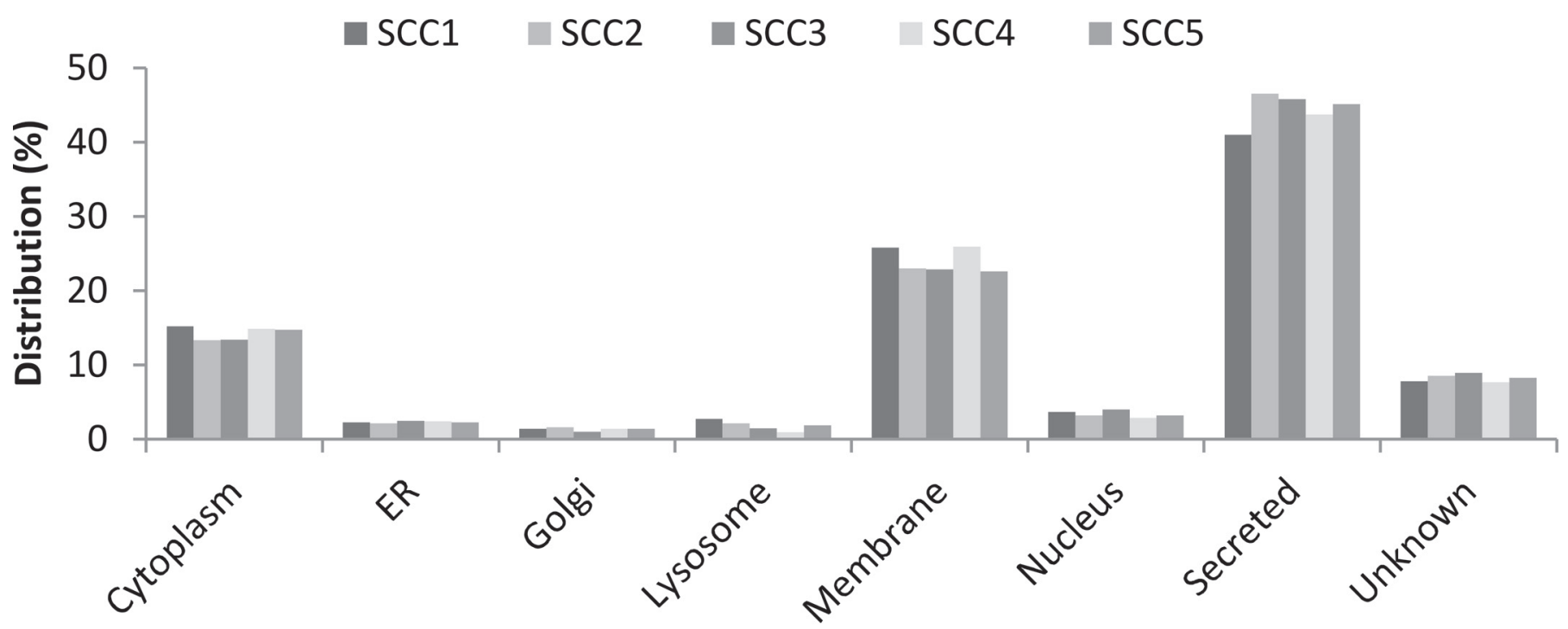

Subcellular location

Figure 2. Subcellular location classification of proteins in bovine milk with different level of SCC $\left(\mathrm{SCC} 1=<10^{5}\right.$ cells $/ \mathrm{mL}$; SCC2 $=2.5 \times$ $10^{5}$ cells $/ \mathrm{mL} ; \mathrm{SCC} 3=4 \times 10^{5}$ cells $/ \mathrm{mL} ; \mathrm{SCC} 4=7.5 \times 10^{5}$ cells $/ \mathrm{mL}$; SCC5 $=10^{6}$ cells $/ \mathrm{mL}$ ). ER $=$ endoplasmic reticulum.

showed an increase in the milk samples with high SCC compared with low SCC.

Next, a comparison was made between milk from cows with highest SCC (SCC5, $10^{6}$ cells $/ \mathrm{mL}$ ) and milk with lowest SCC ( $\mathrm{SCC} 1,<10^{5}$ cells $/ \mathrm{mL}$ ), as shown in Figure 3 . These significantly different proteins had more than 2 -fold changes ( $\log _{2}$ ratio beyond -1 and 1 ), which was reported as the cut-off level by previous studies (Lu et al., 2011, 2013). Nine of the quantified proteins showed a more than 2-fold increase in milk with highest SCC, as shown in Figure 3, whereas 12 of them showed a more than 2-fold decrease. Among these upregulated proteins, most are related to the immune system, such as cathelicidins, $\alpha$-1-microglobulin (AMBP), IGHG2, ITIH4, and S100 calcium-binding protein A8 (S100A8). The most significantly changed protein [cathelicidin 4 (CATHL4)] showed an almost 10-fold increase in the milk from cows with the highest SCC. The upregulation of these proteins was similar to what we found in a preliminary experiment conducted by the same techniques (Supplemental Table S3; http://dx.doi.org/10.3168/ jds.2014-9279). Of the downregulated proteins, platelet glycoprotein 4 (CD36), butyrophilin subfamily 1 member A1 (BTN1A1), and perilipin-2 (PLIN2) are related to lipid synthesis and secretion; ATP-binding cassette subfamily $\mathrm{G}$ member 2 (ABCG2) is related to milk secretion; lactadherin (MFGE8) is involved in cell apoptosis; and CD59 glycoprotein (CD59) is related to the immune system. The concentration of platelet glycoprotein 4 was about 20 -fold lower in milk from cows with highest SCC, as shown in Figure 3.
In addition, the correlation between the concentration of proteins and SCC was calculated to find potential biomarkers for subclinical mastitis (Supplemental Table S4; http://dx.doi.org/10.3168/jds.2014-9279). Among the immune-related proteins, the concentration of PTGDS showed the strongest linear relation with SCC (Figure 4A). The increase in both PTGDS and SCC had the same order of magnitude, showing a 10-fold increase in PTGDS with a 10-fold increase in SCC. A similar correlation between PTGDS and SCC was also found in a preliminary experiment as shown in Supplemental Table S3 (http://dx.doi.org/10.3168/ jds.2014-9279). Next, this correlation was confirmed by an ELISA (Figure 4B). Finally, to know whether the concentration of PTGDS correlates with SCC in individual cows, the concentration of PTGDS from 28 individual milk samples with SCC ranging from $1 \times 10^{5}$ to $8.5 \times 10^{5}$ cells $/ \mathrm{mL}$ were determined using the same ELISA assay, as shown in Figure 4C. Even though the correlation between PTGDS and SCC in the individual cows was not very strong, there was a similar direction in the relation, as well as similar absolute values, in the individual cows.

\section{DISCUSSION}

\section{Protein Identification}

In the current study, a total of 273 proteins were identified in bovine milk serum by one-dimensional SDS-PAGE followed by nanoLC-Orbitrap-MS/MS. 
A similar number of proteins, 269 (including 232 in bovine milk fat globule membrane and 192 in bovine milk serum), were identified in a previous study using the same proteomics techniques (Hettinga et al., 2011). We found several low-abundant immune-related proteins [S100 calcium-binding protein A2 (S100A2), S100 calcium-binding protein A8 (S100A8), S100 calcium-binding protein A9 (S100A9), serum amyloid A-1 protein (SAA1), serum amyloid A-3 protein (SAA3), cathelicidins] in milk from both healthy cows and cows with high SCC (up to $10^{6}$ cells $/ \mathrm{mL}$ ), whereas these proteins were previously only identified in bovine milk from cows with clinical mastitis (Alonso-Fauste et al., 2012). This may be attributed to the high sensitivity of the proteomics technique applied in this study.

The absence of changes in protein and DM contents (Table 1) in milk with high SCC is in accordance with an earlier study (Ogola et al., 2007). The decreasing trend in lactose (Table 1) agrees with what has been reported previously (Ogola et al., 2007). Moreover, the number of identified proteins and their distribution over biological functions and subcellular locations was similar in milk samples at different SCC levels (Figures 1 and 2). Milk at all SCC levels contained a large number of immune-related proteins as well as secreted proteins (Figures 1 and 2). The data show that the difference between milk from healthy cows and cows with subclinical mastitis is not related to the presence or absence of proteins but is caused by their expression levels, as will be discussed next.

\section{Protein Quantification}

To study differences in expression levels of milk proteins, FASP combined with dimethyl labeling was used for quantitative analysis. The results of this quantitative analysis show many differences in the concentration of proteins, including both immune-related proteins and proteins with other biological functions, such as cellular functions, transport, enzymes, and protease inhibitors, as shown in Supplemental Table S2 (http:/ / dx.doi.org/10.3168/jds.2014-9279). The increase of free CN (or CN peptides) in the milk serum with high SCC samples (Table 2) is consistent with the decrease of micellar CN described in a previous study (Forsbäck et al., 2010). As SCC increased, proteolysis also increased (Larsen et al., 2010), which thereby results in the increase of free $\mathrm{CN}$, or $\mathrm{CN}$ peptides, in the milk serum. A more comprehensive study of these $\mathrm{CN}$ peptides would, however, require a different technological approach than what was used in this study. The concentration of specific immune-related proteins (all cathelicidins, IGHG2, ITIH4) increased in all samples with high SCC but not proportionally with SCC (Table 2). Chiaradia, et al. (2013) reported that also in ovine milk, the proteins upregulated with mammary gland infection did not increase proportionately with SCC (Chiaradia et al., 2013). They believed this could be due to different processes occurring during subclinical mastitis because the increase of SCC in milk is not only caused by the bacterial infection but also by the stressful conditions and a probable metabolic impairment of the mammary gland (Chiaradia et al., 2013).

\section{Upregulated Proteins in Milk from Cows with High SCC}

There were 10 proteins that showed a more than 2 -fold increase in milk serum with an average SCC of $10^{6}$ cells $/ \mathrm{mL}$ compared with milk serum with an average SCC of $10^{5}$ cells $/ \mathrm{mL}$, as shown in Figure 3. Of these upregulated proteins, 3 proteins were cathelicidins. Their concentration increased significantly in milk serum from cows with subclinical mastitis (Figure 3), which was also found in milk from cows with mastitis after E. coli or Streptococcus uberis invasion (Lippolis and Reinhardt, 2005; Boehmer et al., 2008; Smolenski et al., 2011). This may be related to the antimicrobial activity of cathelicidins as well as their role in modulation of the innate and adaptive immune response (Tecle et al., 2010). The significant increase in immunoglobulins (IGHG2 and IGK) and acute phase proteins (S100 calcium-binding protein A8 and ITIH4) in the milk with high SCC (Figure 3) has been discussed frequently in the previous studies (Caffin and Poutrel, 1988; Mitterhuemer et al., 2010; Alonso-Fauste et al., 2012; Huang et al., 2014). Protease inhibitors play a crucial role in the regulation of protease activity originating from neutrophils (Owen and Campbell, 1999). Serine protease inhibitors have been shown to protect tissue against damage that can be caused by proteases secreted by neutrophils during an infection (Thompson and Ohlsson, 1986). For this reason, the observed increase in SERPINA3 in the milk with high SCC (Figure 3) might be related to the protection of mammary gland cells.

\section{Downregulated Proteins in Milk from Cows with High SCC}

As shown in Figure 3, 12 proteins were more than 2 -fold downregulated in milk with the highest versus the lowest SCC. Most of the downregulated proteins were related to other biological functions than immune protection, for example, lipid metabolism (platelet glycoprotein 4 20-fold, butyrophilin subfamily 1 member A1 4-fold, and perilipin-2 6-fold). The downregulation of all these proteins has been reported before in milk 
Table 2. The ratios of common proteins and immune-related proteins between samples at different SCC levels $\left(\mathrm{SCC} 1=<10^{5}\right.$ cells $/ \mathrm{mL}$; SCC2 $=2.5 \times 10^{5}$ cells $/ \mathrm{mL} ; \mathrm{SCC} 3=4 \times 10^{5}$ cells $/ \mathrm{mL} ; \mathrm{SCC} 4=7.5 \times 10^{5}$ cells $/ \mathrm{mL} ;$ SCC $5=10^{6}$ cells $/ \mathrm{mL}$ )

\begin{tabular}{|c|c|c|c|c|c|c|c|}
\hline Uniprot ID & Protein name & Gene name & $\begin{array}{l}\text { Biological } \\
\text { function }^{1}\end{array}$ & $\begin{array}{l}\mathrm{SCC} 2 / \\
\mathrm{SCC}^{2}\end{array}$ & $\begin{array}{l}\text { SCC3/ } \\
\text { SCC1 }^{2}\end{array}$ & $\begin{array}{l}\mathrm{SCC} 4 / 2 \\
\mathrm{SCC}^{2}\end{array}$ & $\begin{array}{l}\text { SCC5/2 } \\
\text { SCC1 }^{2}\end{array}$ \\
\hline P33046 & Cathelicidin- 4 & CATHL4 & Immunity & 3.64 & NQ & NQ & 9.82 \\
\hline O02853 & Prostaglandin-H2 D-isomerase & $P T G D S$ & Enzyme & 1.98 & 3.163 & 5.849 & 7.144 \\
\hline P19660 & Cathelicidin-2 & CATHL2 & Immunity & NQ & 4.96 & 4.75 & 4.2 \\
\hline G3N0V0 & Ig $\gamma-2$ chain $\mathrm{C}$ region & $I G H G 2$ & Immunity & 2.119 & 2.755 & 1.77 & 2.638 \\
\hline Q3T052 & $\begin{array}{l}\text { Inter- } \alpha \text {-trypsin inhibitor heavy } \\
\text { chain } \mathrm{H} 4\end{array}$ & $\mathrm{ITIH}_{4}$ & Immunity & NQ & 3.12 & 1.36 & 2.19 \\
\hline G3N1U4 & Serpin A3-8 & SERPINA3-8 & $\begin{array}{l}\text { Protease } \\
\text { inhibitor }\end{array}$ & 1.18 & 1.446 & 1.152 & 2.042 \\
\hline P61823 & Ribonuclease pancreatic & $R N A S E 1$ & Enzyme & 1.309 & 1.069 & 2.429 & 1.929 \\
\hline $\mathrm{P} 17697$ & Clusterin & $C L U$ & Immunity & 1.764 & 5.09 & 3.621 & 1.733 \\
\hline P60712 & Actin, cytoplasmic 1 & $A C T B$ & $\begin{array}{l}\text { Protein } \\
\text { synthesis }\end{array}$ & 1.756 & 1.198 & 2.224 & 1.63 \\
\hline Q0IIA2 & Odorant-binding protein-like & $M G C 151921$ & Transport & 1.597 & 3.067 & 1.353 & 1.507 \\
\hline G3N1R1 & $\begin{array}{l}\text { Hyaluronan and proteoglycan link } \\
\text { protein } 1\end{array}$ & $H A P L N 1$ & Immunity & 1.193 & 2.557 & 2.248 & 1.328 \\
\hline P80195 & $\begin{array}{l}\text { Glycosylation-dependent cell } \\
\text { adhesion molecule } 1\end{array}$ & GLYCAM1 & Immunity & 0.83 & 1.021 & 1.599 & 1.326 \\
\hline Q29443 & Serotransferrin & $T F$ & Transport & 1.344 & 1.549 & 1.752 & 1.308 \\
\hline Q2UVX4 & Complement C3 & C3 & Immunity & 1.565 & 1.502 & 1.589 & 1.283 \\
\hline P80025 & Lactoperoxidase & $L P O$ & Immunity & 1.078 & 0.865 & 1.271 & 1.279 \\
\hline P31096 & Osteopontin & $S P P 1$ & Cell & 1.603 & 2.982 & 0.948 & 1.276 \\
\hline $\mathrm{P} 02663$ & $\alpha-\mathrm{S} 2-\mathrm{CN}$ & CSN1S2 & Transport & 0.982 & 1.163 & 2.193 & 1.259 \\
\hline A5D7Q2 & TAP binding protein (Tapasin) & $T A P B P$ & Immunity & 2.064 & 1.53 & 2.339 & 1.211 \\
\hline Q3ZCH5 & Zinc- $\alpha$-2-glycoprotein & $A Z G P 1$ & Immunity & 1.138 & 1.045 & 0.986 & 1.195 \\
\hline P81265 & $\begin{array}{l}\text { Polymeric immunoglobulin } \\
\text { receptor }\end{array}$ & $P I G R$ & Immunity & 1.212 & 1.09 & 1.327 & 1.167 \\
\hline Q3T101 & IGL@ & $I G L @$ & Immunity & 1.606 & 2.202 & 1.887 & 1.151 \\
\hline B5B0D4 & Major allergen $\beta$-LG & & Transport & 0.619 & 0.948 & 0.952 & 0.989 \\
\hline Q2KIS7 & Tetranectin & CLEC3B & Cell & 0.909 & 0.88 & 0.889 & 0.978 \\
\hline Q95122 & $\begin{array}{l}\text { Monocyte differentiation antigen } \\
\text { CD14 }\end{array}$ & $C D 14$ & Immunity & 1.078 & 1.014 & 0.983 & 0.962 \\
\hline Q3SZR3 & $\alpha$-1-acid glycoprotein & ORM1 & Transport & 1.132 & 0.913 & 0.733 & 0.94 \\
\hline Q9TRB9 & $\begin{array}{l}\text { Enterotoxin-binding glycoprotein } \\
\text { PP20K }\end{array}$ & & Unknown & 1.073 & 1.05 & 0.874 & 0.933 \\
\hline Q3MHN5 & Vitamin D-binding protein & $G C$ & Transport & 1.151 & 0.992 & 1.175 & 0.925 \\
\hline Q3ZCL0 & Cysteine-rich secretory protein 3 & CRISP3 & Immunity & 1.228 & 1.647 & 1.279 & 0.919 \\
\hline Q28049 & $\alpha-\mathrm{LA}$ & $L A L B A$ & Enzyme & 0.726 & 0.77 & 1.118 & 0.917 \\
\hline P17690 & $\beta$-2-glycoprotein 1 & $A P O H$ & Coagulation & 0.528 & 1.019 & 1.638 & 0.891 \\
\hline Q29RQ1 & Complement component $\mathrm{C} 7$ & $C 7$ & Immunity & NQ & 1.38 & 0.99 & 0.89 \\
\hline Q0P569 & Nucleobindin-1 & NUCB1 & $\begin{array}{l}\text { Protein } \\
\text { synthesis }\end{array}$ & 1.252 & 0.998 & 0.945 & 0.881 \\
\hline Q9MZ06 & $\begin{array}{l}\text { Fibroblast growth factor-binding } \\
\text { protein } 1\end{array}$ & $F G F B P 1$ & Cell & 1.197 & 0.758 & 0.826 & 0.852 \\
\hline P02702 & Folate receptor $\alpha$ & FOLR1 & $\begin{array}{l}\text { Protein } \\
\text { synthesis }\end{array}$ & 1.124 & 1.049 & 0.839 & 0.772 \\
\hline A8YXY3 & $15 \mathrm{kDa}$ selenoprotein & SEP15 & $\begin{array}{l}\text { Protein } \\
\text { synthesis }\end{array}$ & 1 & 0.996 & 0.835 & 0.696 \\
\hline P10790 & Fatty acid-binding protein, heart & FABP3 & Transport & 0.942 & 0.606 & 1.205 & 0.687 \\
\hline
\end{tabular}


Table 2 (Continued). The ratios of common proteins and immune-related proteins between samples at different $\mathrm{SCC}$ levels $\left(\mathrm{SCC} 1=<10^{5}\right.$ cells $/ \mathrm{mL} ; \mathrm{SCC} 2=2.5 \times 10^{5}$ cells $/ \mathrm{mL} ; \mathrm{SCC} 3=4 \times 10^{5}$ cells $/ \mathrm{mL} ; \mathrm{SCC} 4=7.5 \times 10^{5}$ cells $/ \mathrm{mL} ; \mathrm{SCC} 5=10^{6}$ cells $/ \mathrm{mL}$ )

\begin{tabular}{|c|c|c|c|c|c|c|c|}
\hline Uniprot ID & Protein name & Gene name & $\begin{array}{l}\text { Biological } \\
\text { function }^{1}\end{array}$ & $\begin{array}{l}\mathrm{SCC} 2 / \\
\mathrm{SCC}^{2}\end{array}$ & $\begin{array}{l}\mathrm{SCC} 3 / 2 \\
\mathrm{SCC}^{2}\end{array}$ & $\begin{array}{l}\mathrm{SCC} 4 / \\
\mathrm{SCC}^{2}\end{array}$ & $\begin{array}{l}\mathrm{SCC} 5 \\
\mathrm{SCC}^{2}\end{array}$ \\
\hline F1MUT3 & Xanthine dehydrogenase/oxidase & $X D H$ & Enzyme & 1.341 & 0.528 & 1.079 & 0.638 \\
\hline P12799 & Fibrinogen $\gamma$-B chain & $F G G$ & Coagulation & 1.207 & 1.308 & 1.678 & 0.547 \\
\hline P02672 & Fibrinogen $\alpha$ chain & $F G A$ & Coagulation & 1.34 & 1.181 & 1.577 & 0.417 \\
\hline Q32PA1 & $\begin{array}{l}\text { CD59 molecule, complement } \\
\text { regulatory protein }\end{array}$ & $C D 59$ & Immunity & NQ & 0.26 & 1.35 & 0.35 \\
\hline P02668 & Kappa-CN & CSN3 & Transport & 0.108 & 0.281 & 1.065 & 0.233 \\
\hline Q95114 & Lactadherin & $M F G E 8$ & Cell & 1.003 & 0.24 & 1.323 & 0.179 \\
\hline P18892 & $\begin{array}{l}\text { Butyrophilin subfamily } 1 \text { member } \\
\text { A1 }\end{array}$ & $B T N 1 A 1$ & Transport & 0.829 & 0.135 & 1.375 & 0.156 \\
\hline Q27960 & $\begin{array}{l}\text { Sodium-dependent phosphate } \\
\text { transport protein } 2 \mathrm{~B}\end{array}$ & SLC34A2 & Transport & 1.153 & 0.107 & 1.135 & 0.106 \\
\hline P26201 & Platelet glycoprotein 4 & $C D 36$ & Cell & 0.946 & 0.027 & 1.143 & 0.046 \\
\hline
\end{tabular}

${ }^{1}$ The biological functions were found using Uniprot (http://www.uniprot.org/) and DAVID (Dennis et al., 2003); Cell includes cell adhesion, cell mobility, cell growth, and cell apoptosis.

${ }^{2}$ Values more than one mean upregulated in milk with high SCC compared with milk with low SCC, whereas the values less than one mean downregulated in milk with high SCC compared with milk with low SCC. NQ = not quantified.

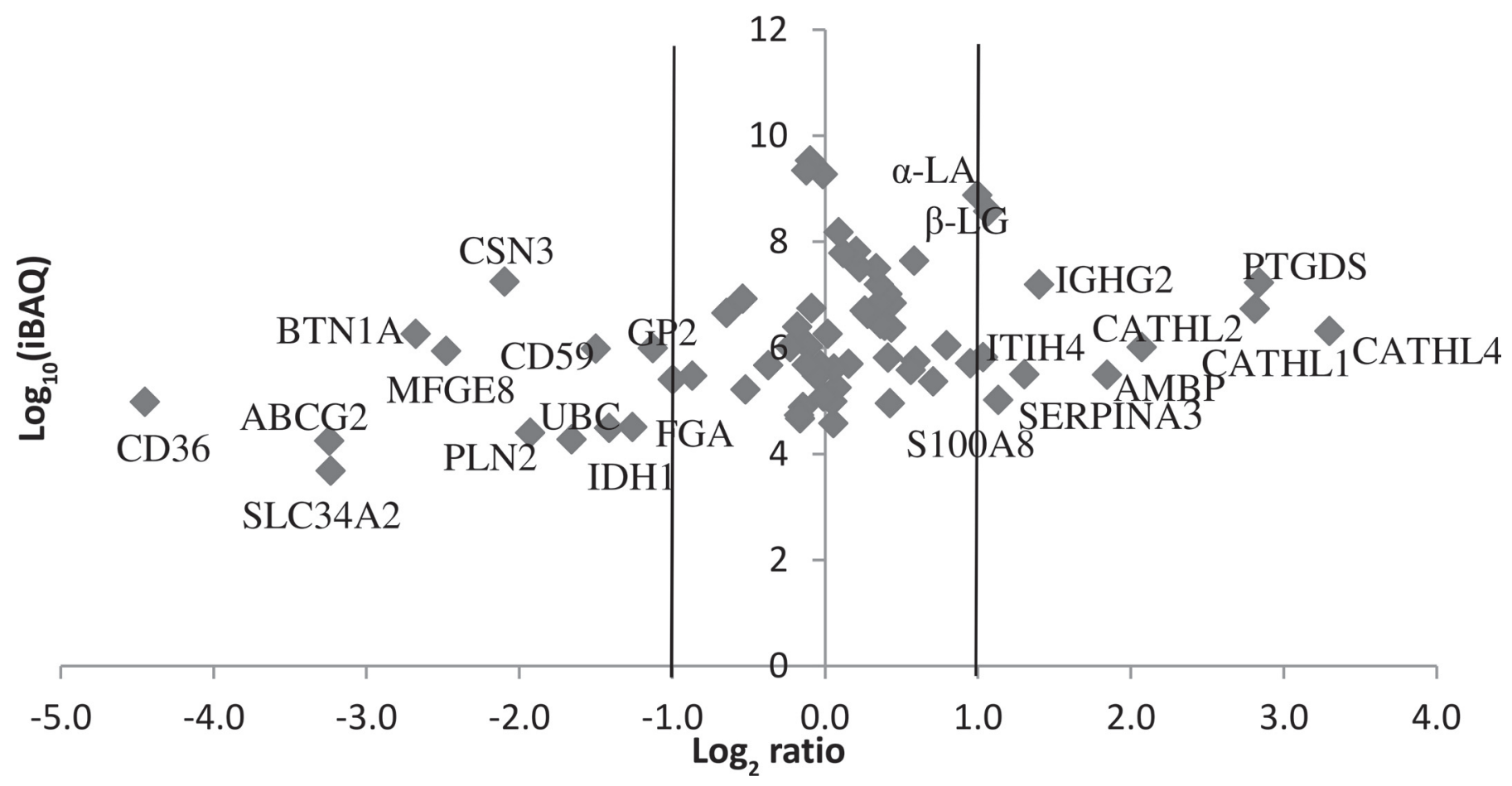

Figure 3. $\log _{2}$ ratio of protein concentration in milk with the highest SCC (SCC5 $=10^{6}$ cells $/ \mathrm{mL}$ ) compared with milk with the lowest SCC $\left(\mathrm{SCC} 1=<10^{5}\right.$ cells $\left./ \mathrm{mL}\right) . \mathrm{iBAQ}=$ intensity-based absolute quantification; ABCG2 = ATP-binding cassette subfamily $\mathrm{G}$ member $2 ; \mathrm{S} 100 \mathrm{~A} 8=$ S100 calcium-binding protein A8; AMBP = $\alpha$-1-microglobulin. Other abbreviations are defined in Table 2. 


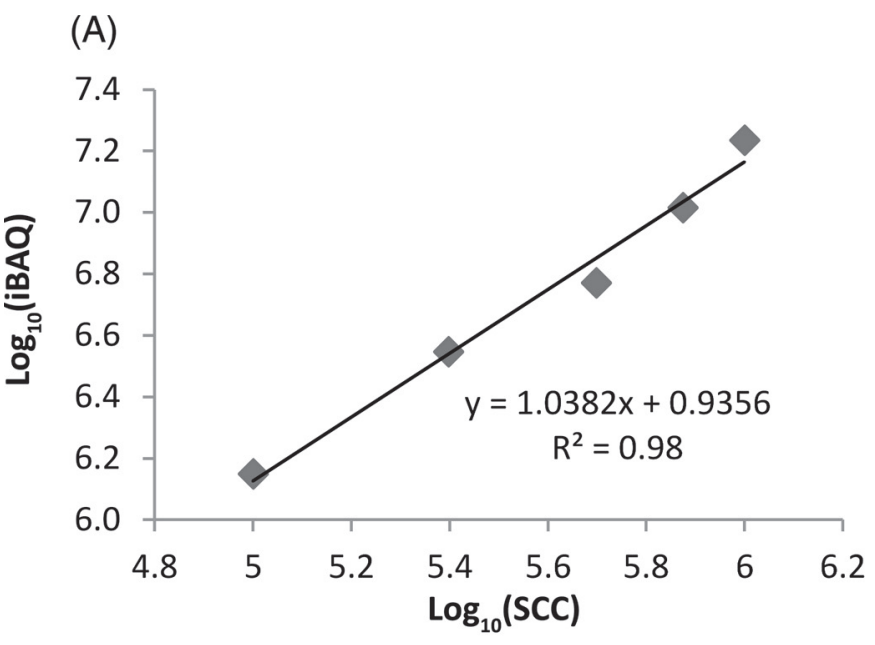

(B)

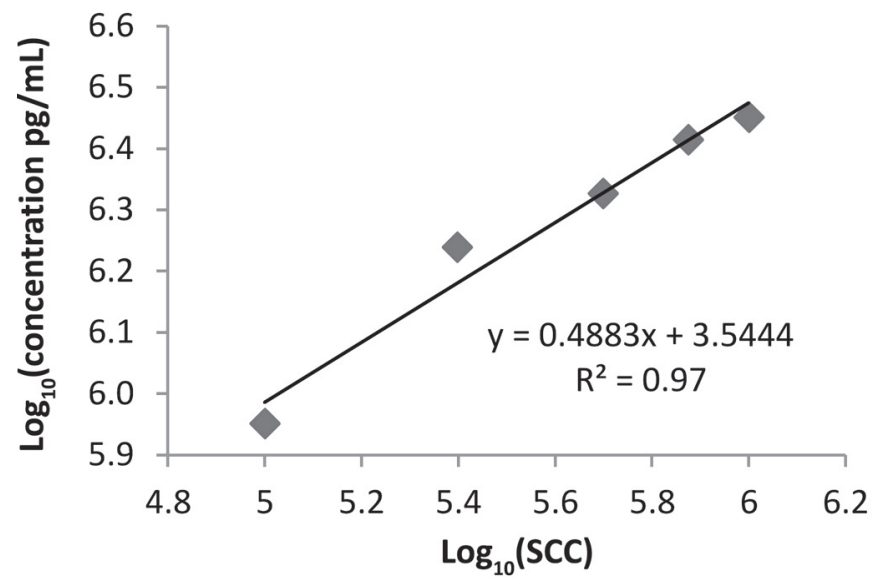

(C)

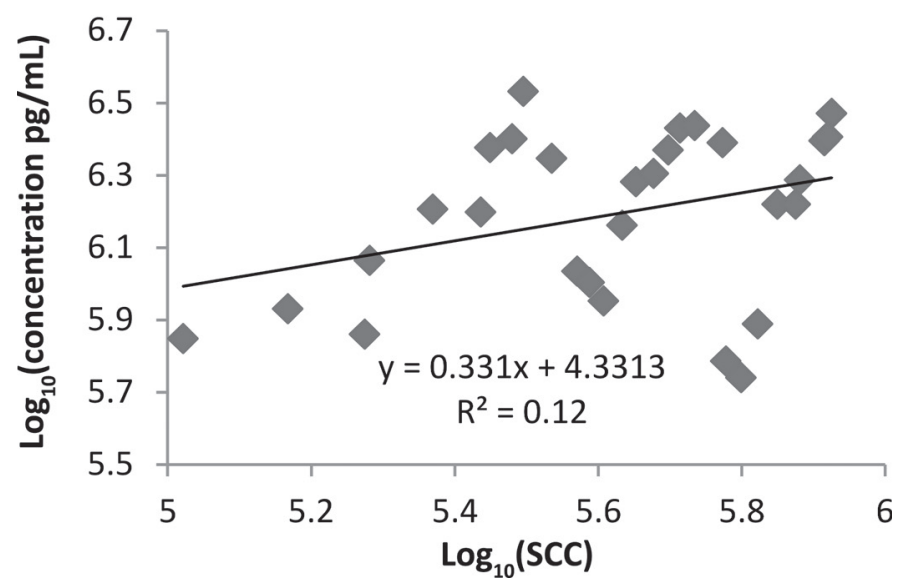

Figure 4. Relation between SCC and prostaglandin-H2 D-isomerase (PTGDS) concentration. (A) The relation between SCC and the concentration of PTGDS in 5 bulk-milk samples from 100 cows determined by liquid chromatography-tandem mass spectrometry. (B) The relation between SCC and the concentration of PTGDS in 5 bulk milk samples from 100 cows determined by ELISA. (C) The relation between SCC and the concentration of PTGDS in the milk from 28 individual cows determined by ELISA. iBAQ = intensity-based absolute quantification. from cows with mastitis (Moyes et al., 2009; Huang et al., 2014). These changes in concentration of cellular function proteins were related to the immune response to mastitis infection (Genini et al., 2011). Because the complement regulatory protein CD59 can protect the mammary gland from overactivated complement mediated cell lysis and tissue damage (Bjorge et al., 1996), the decrease of CD59 in milk with high SCC (Figure 3) indicates its protective effect for the mammary gland during inflammation. Lactadherin (MFGE8) mediates phagocytosis of apoptotic epithelial cells. Downregulated MFGE8 can result in inefficient engulfment of dead cells by phagocytes (Boutet et al., 2004) and this delayed apoptosis would lead to necrotic cell death, which is believed to induce inflammation. Therefore, the decrease of cellular function proteins CD59 and MFGE8, as found in this study, indicates a stimulation of the immune response against inflammation.

\section{Correlation Between PTGDS and SCC}

The same linear correlation between PTGDS and SCC obtained from both LC-MS/MS results and ELISA (Figure 4A and 4B) shows the quantitative precision of the LC-MS/MS approach used in this study. The increase of PTGDS in the milk with high SCC was consistent with its increase in the milk from mastitis cows reported by Baeker et al. (2002). They hypothesized that the upregulation of PTGDS in milk was either the result of overexpression or damage of the blood-milk barrier caused by mastitis (Baeker et al., 2002). In addition, prostaglandins have been shown to induce chemokines resulting in infiltration of inflammatory cells, such as neutrophils, eosinophils, and macrophages (Aoki and Narumiya, 2012). This reflects that epithelial cells may produce PTGDS during mastitis to recruit the necessary immune cells through converting prostaglandin $\mathrm{H} 2$ to prostaglandin D2 (Figure 5), resulting in an increase in SCC. Although cathelicidins have been reported to be a biomarker for mastitis or subclinical mastitis, the correlation between cathelicidins and SCC was lower than the correlation between PTGDS and SCC (Supplemental Table S4; http:// dx.doi.org/10.3168/jds.2014-9279). The nonlinear increase of cathelicidins was also reported by Smolenski et al. (2011), who suggested that it might be caused by a variation in neutrophil concentration and activity at different stages of subclinical mastitis. The higher correlation between PTGDS and SCC indicates that PTGDS may be a more suitable indicator for bulk-milk SCC. However, it seems to be not suitable for testing of milk from individual cows (Figure 4C). This inability to predict SCC of individual cow milk may be due to variation in the immune response between cows at 


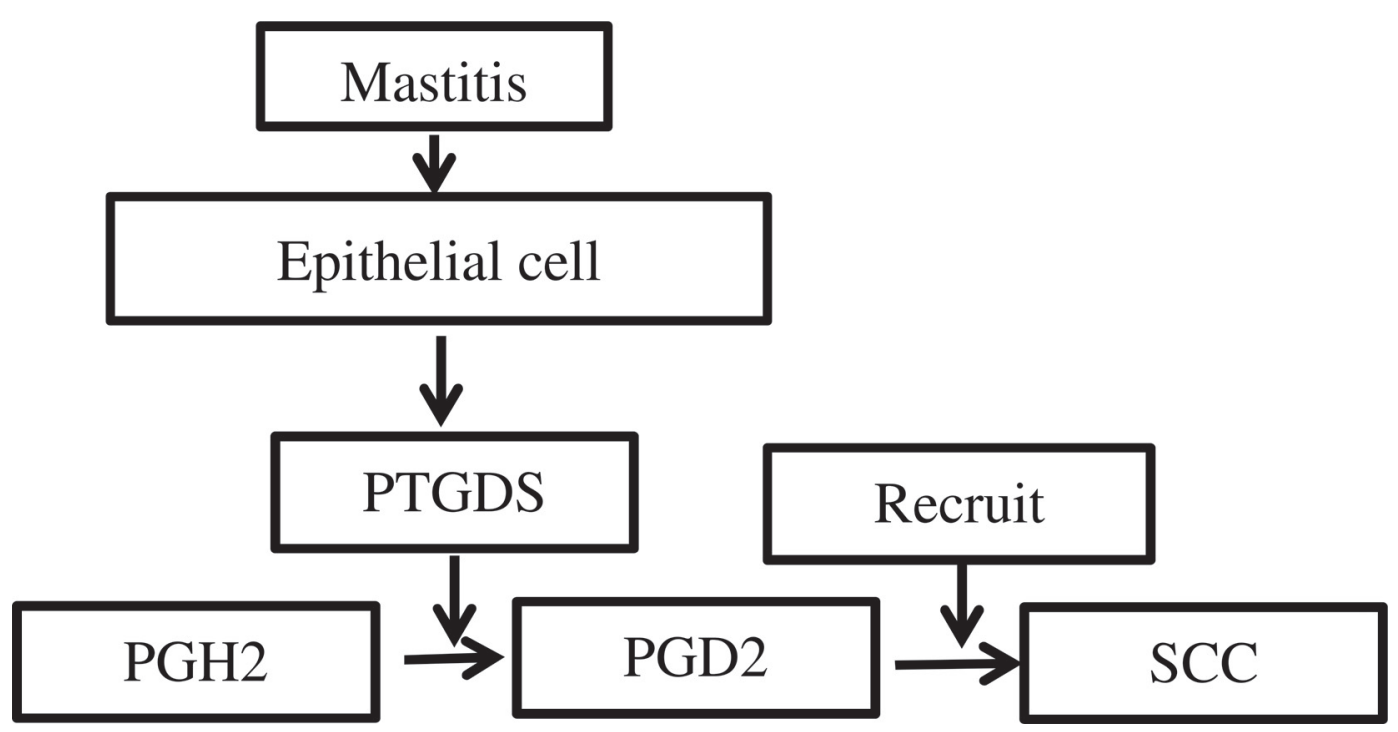

Figure 5. The role of prostaglandin-H2 D-isomerase (PTGDS) in the recruitment of SCC in the mammary gland from cows with mastitis inflammation $(\mathrm{PGH} 2$ = prostaglandin H2; PGD2 = prostaglandin D2), based on studies by Bonnefoy and Legrand (2000), Baeker et al. (2002), and Aoki and Narumiya (2012).

different stages of mastitis, which has been described before by Smolenski et al. (2011).

Bulk milk is used in the dairy industry for commercial production of dairy products. Therefore, a simple and easy test could be beneficial to distinguish bulk milk with high versus low SCC. Prostaglandin-H2 Disomerase may thus be a potential candidate for such an easy test, which could for example be a color test or lab-on-a-chip assay. Such tests for enzymes in milk have previously already been developed for other enzymes such as the alkaline phosphatase assay for the validation of correct milk pasteurization (Rankin et al., 2010). According to the ELISA, the concentration of PTGDS in milk is above the detection limits of alkaline phosphatase assay, suggesting the feasibility of developing an easy color test. Such a test may be cheaper and simpler than advanced instruments such as the Fossomatic. In addition, PTGDS, in comparison with SCC, may provide additional insights in the mechanisms of mammary gland defense during infections if it would give additional information related to the stage of mastitis.

The effect of high SCC of cows on changes in their milk composition and subsequent effects on the quality of dairy products have been previously reported to be associated with increased proteolysis. For instance, milk with a high SCC level can lead to the development of off-flavors in pasteurized milk, UHT milk, yogurts, and cheese because of lipolysis and proteolysis (Maréchal et al., 2011). Elevated levels of FFA have been associated with rancidity, and extensive proteolysis in milk could produce more hydrophobic peptides resulting in bitterness and astringency (Maréchal et al., 2011). Moreover, the shelf life of these dairy products were also shortened because of relatively high proteolytic activity in the milk with high SCC (Datta and Deeth, 2001; Santos et al., 2003; Maréchal et al., 2011). In addition, high SCC in milk also influences the coagulation properties and leads to increased moisture content and lower cheese yield (Barbano et al., 1991), resulting in economic losses. An easy and cheap test based on PTGDS could help separate milk with high SCC and thus avoid these negative influences on dairy product quality.

\section{CONCLUSIONS}

This is the first study investigating the qualitative and quantitative differences of the milk proteome from cows with different levels of SCC (range: $10^{5}$ to $10^{6}$ cells $/ \mathrm{mL}$ ). The results from this study indicate that the influence of high SCC is not related to the presence or absence of specific proteins but mainly involves the expression level of proteins. These results thereby contribute to better understanding of the influence of subclinical mastitis on the changes of the milk proteome, as well as the biological phenomena occurring in the mammary gland. The strong linear relation between PTGDS and SCC indicates that PTGDS may be a good candidate for developing a simple and easy test to evaluate bulk milk quality, by separating milk with high SCC to increase milk suitability for further milk processing. To understand the possible recruitment role 
of PTGDS on SCC, further studies on the mechanism underlying the relation between PTGDS and SCC may be helpful.

\section{REFERENCES}

Alonso-Fauste, I., M. Andrés, M. Iturralde, F. Lampreave, J. Gallart, and M. A. Álava. 2012. Proteomic characterization by 2-DE in bovine serum and whey from healthy and mastitis affected farm animals. J. Proteomics 75:3015-3030.

Aoki, T., and S. Narumiya. 2012. Prostaglandins and chronic inflammation. Trends Pharmacol. Sci. 33:304-311.

Awale, M. M., G. B. Dudhatra, K. Avinash, B. N. Chauhan, D. R Kaman, C. M. Modi, H. B. Patel, and S. K. Mody. 2012. Bovine mastitis: A threat to economy. Sci. Rep. 1:1-10.

Baeker, R., S. Haebel, K. Schlatterer, and B. Schlatterer. 2002. Lipocalin-type prostaglandin D synthase in milk: a new biomarker for bovine mastitis. Prostaglandins Other Lipid Mediat. 67:75-88.

Barbano, D. M., R. R. Rasmussen, and J. M. Lynch. 1991. Influence of milk somatic cell count and milk age on cheese yield. J. Dairy Sci. 74:369-388.

Batavani, R. A., S. Asri, and H. Naebzadeh. 2007. The influence of subclinical mastitis on milk composition in dairy cows. Iranian J. Vet. Res. 8:205-211.

Bjorge, L., T. S. Jensen, E. K. Kristoffersen, M. Ulstein, and R. Matre. 1996. Identification of the complement regulatory protein CD59 in human colostrum and milk. Am. J. Reprod. Immunol. 35:43-50.

Boehmer, J. L., D. D. Bannerman, K. Shefcheck, and J. L. Ward. 2008. Proteomic analysis of differentially expressed proteins in bovine milk during experimentally induced Escherichia coli mastitis. J. Dairy Sci. 91:4206-4218.

Boersema, P. J., R. Raijmakers, S. Lemeer, S. Mohammed, and A. J. Heck. 2009. Multiplex peptide stable isotope dimethyl labeling for quantitative proteomics. Nat. Protoc. 4:484-494.

Bonnefoy, A., and C. Legrand. 2000. Proteolysis of subendothelial adhesive glycoproteins (fibronectin, thrombospondin, and von Willebrand factor) by plasmin, leukocyte cathepsin $\mathrm{G}$, and elastase. Thromb. Res. 98:323-332.

Boutet, P., D. Boulanger, L. Gillet, A. Vanderplasschen, R. Closset, F. Bureau, and P. Lekeux. 2004. Delayed neutrophil apoptosis in bovine subclinical mastitis. J. Dairy Sci. 87:4104-4114.

Caffin, J. P., and B. Poutrel. 1988. Physiological and pathological factors influencing bovine immunoglobulin G2 concentration in milk. J. Dairy Sci. 71:2035-2043.

Chiaradia, E., A. Valiani, M. Tartaglia, F. Scoppetta, G. Renzone, S. Arena, L. Avellini, S. Benda, A. Gaiti, and A. Scaloni. 2013. Ovine subclinical mastitis: Proteomic analysis of whey and milk fat globules unveils putative diagnostic biomarkers in milk. J. Proteomics 83:144-159.

Cox, J., and M. Mann. 2008. MaxQuant enables high peptide identification rates, individualized p.p.b.-range mass accuracies and proteome-wide protein quantification. Nat. Biotechnol. 26:13671372.

Cox, J., N. Neuhauser, A. Michalski, R. A. Scheltema, J. V. Olsen, and M. Mann. 2011. Andromeda: A peptide search engine integrated into the MaxQuant environment. J. Proteome Res. 10:1794-1805.

Datta, N., and H. C. Deeth. 2001. Age gelation of UHT milk-A review. Food Bioprod. Process. 79:197-210.

Dennis, G. Jr., B. T. Sherman, D. A. Hosack, J. Yang, W. Gao, H. C. Lane, and R. A. Lempicki. 2003. DAVID: Database for annotation, visualization, and integrated discovery. Genome Biol. 4:3.

Forsbäck, L., H. Lindmark-Månsson, A. Andrén, and K. SvennerstenSjaunja. 2010. Evaluation of quality changes in udder quarter milk from cows with low-to-moderate somatic cell counts. Animal 4:617-626.

Genini, S., B. Badaoui, G. Sclep, S. C. Bishop, D. Waddington, M. H. Pinard van der Laan, C. Klopp, C. Cabau, H. M. Seyfert, W. Petzl, K. Jensen, E. J. Glass, A. de Greeff, H. E. Smith, M. A. Smits, I. Olsaker, G. M. Boman, G. Pisoni, P. Moroni, B. Castiglioni, P.
Cremonesi, M. Del Corvo, E. Foulon, G. Foucras, R. Rupp, and E. Giuffra. 2011. Strengthening insights into host responses to mastitis infection in ruminants by combining heterogeneous microarray data sources. BMC Genomics 12:225.

Hagiwara, S. I., K. Kawai, A. Anri, and H. Nagahata. 2003. Lactoferrin concentrations in milk from normal and subclinical mastitic cows. J. Vet. Med. Sci. 65:319-323.

Hettinga, K., H. van Valenberg, S. de Vries, S. Boeren, T. van Hooijdonk, J. van Arendonk, and J. Vervoort. 2011. The host defense proteome of human and bovine milk. PLoS ONE 6:e19433.

Hinz, K. L. B. Larsen, O. Wellnitz, R. M. Bruckmaier, and A. L. Kelly. 2012. Proteolytic and proteomic changes in milk at quarter level following infusion with Escherichia coli lipopolysaccharide. J. Dairy Sci. 95:1655-1666.

Hogarth, C. J., J. L. Fitzpatrick, A. M. Nolan, F. J. Young, A. Pitt, and P. D. Eckersall. 2004. Differential protein composition of bovine whey: a comparison of whey from healthy animals and from those with clinical mastitis. Proteomics 4:2094-2100.

Huang, J., G. Luo, Z. Zhang, X. Wang, Z. Ju, C. Qi, Y. Zhang, C. Wang, R. Li, J. Li, W. Yin, Y. Xu, S. J. Moisa, J. J. Loor, and J. Zhong. 2014. iTRAQ-proteomics and bioinformatics analyses of mammary tissue from cows with clinical mastitis due to natural infection with Staphylococci aureus. BMC Genomics 15:839.

Koldeweij, E., U. Emanuelson, and L. Janson. 1999. Relation of milk production loss to milk somatic cell count. Acta Vet. Scand. 40:47-56.

Larsen, L. B., K. Hinz, A. L. Jorgensen, H. S. Moller, O. Wellnitz, R. M. Bruckmaier, and A. L. Kelly. 2010. Proteomic and peptidomic study of proteolysis in quarter milk after infusion with lipoteichoic acid from Staphylococcus aureus. J. Dairy Sci. 93:5613-5626.

Lindmark-Månsson, H., C. Bränning, G. Aldén, and M. Paulsson 2006. Relationship between somatic cell count, individual leukocyte populations and milk components in bovine udder quarter milk. Int. Dairy J. 16:717-727.

Lippolis, J. D., and T. A. Reinhardt. 2005. Proteomic survey of bovine neutrophils. Vet. Immunol. Immunopathol. 103:53-65.

Lu, J., E. Antunes Fernandes, A. E. Páez Cano, J. Vinitwatanakhun, S. Boeren, T. van Hooijdonk, A. van Knegsel, J. Vervoort, and K. A. Hettinga. 2013. Changes in milk proteome and metabolome associated with dry period length, energy balance and lactation stage in post parturient dairy cows. J. Proteome Res. 12:3288-3296.

Lu, J., S. Boeren, S. C. de Vries, H. J. van Valenberg, J. Vervoort, and K. Hettinga. 2011. Filter-aided sample preparation with dimethyl labeling to identify and quantify milk fat globule membrane proteins. J. Proteomics 75:34-43.

Malmström, J., M. Beck, A. Schmidt, V. Lange, E. W. Deutsch, and R. Aebersold. 2009. Proteome-wide cellular protein concentrations of the human pathogen Leptospira interrogans. Nature 460:762-765.

Maréchal, C. L., R. Thiéry, E. Vautor, and Y. L. Loir. 2011. Mastitis impact on technological properties of milk and quality of milk products-A review. Dairy Sci. Technol. 91:247-282.

Mitterhuemer, S., W. Petzl, S. Krebs, D. Mehne, A. Klanner, E. Wolf, H. Zerbe, and H. Blum. 2010. Escherichia coli infection induces distinct local and systemic transcriptome responses in the mammary gland. BMC Genomics 11:138.

Moyes, K. M., J. K. Drackley, D. E. Morin, M. Bionaz, S. L. Rodriguez-Zas, R. E. Everts, H. A. Lewin, and J. J. Loor. 2009. Gene network and pathway analysis of bovine mammary tissue challenged with Streptococcus uberis reveals induction of cell proliferation and inhibition of PPARgamma signaling as potential mechanism for the negative relationships between immune response and lipid metabolism. BMC Genomics 10:542.

Ogola, H., A. Shitandi, and J. Nanua. 2007. Effect of mastitis on raw milk compositional quality. J. Vet. Sci. 8:237-242.

Owen, C. A., and E. J. Campbell. 1999. The cell biology of leukocytemediated proteolysis. J. Leukoc. Biol. 65:137-150.

Patterson, T. A., E. K. Lobenhofer, S. B. Fulmer-Smentek, P. J. Collins, T.-M. Chu, W. Bao, H. Fang, E. S. Kawasaki, J. Hager, I. R. Tikhonova, S. J. Walker, L. Zhang, P. Hurban, F. de Longueville, J. C. Fuscoe, W. Tong, L. Shi, and R. D. Wolfinger. 2006. Performance comparison of one-color and two-color platforms within the 
Microarray Quality Control (MAQC) project. Nat. Biotechnol. 24:1140-1150.

Rankin, S. A., A. Christiansen, W. Lee, D. S. Banavara, and A. LopezHernandez. 2010. Invited review: The application of alkaline phosphatase assays for the validation of milk product pasteurization. J. Dairy Sci. 93:5538-5551.

Safi, S., A. Khoshvaghti, S. R. Jafarzadeh, M. Bolourchi, and I. Nowrouzian. 2009. Acute phase proteins in the diagnosis of bovine subclinical mastitis. Vet. Clin. Pathol. 38:471-476.

Santos, M. V., Y. Ma, and D. M. Barbano. 2003. Effect of somatic cell count on proteolysis and lipolysis in pasteurized fluid milk during shelf-life storage. J. Dairy Sci. 86:2491-2503.

Schrick, F. N., M. E. Hockett, A. M. Saxton, M. J. Lewis, H. H. Dowlen, and S. P. Oliver. 2001. Influence of subclinical mastitis during early lactation on reproductive parameters. J. Dairy Sci. 84:1407-1412.

Schwanhausser, B., D. Busse, N. Li, G. Dittmar, J. Schuchhardt, J. Wolf, W. Chen, and M. Selbach. 2011. Global quantification of mammalian gene expression control. Nature 473:337-342.

Smolenski, G. A., R. J. Wieliczko, S. M. Pryor, M. K. Broadhurst, T. T. Wheeler, and B. J. Haigh. 2011. The abundance of milk cathelicidin proteins during bovine mastitis. Vet. Immunol. Immunopathol. 143:125-130.

Tecle, T., S. Tripathi, and K. L. Hartshorn. 2010. Review: Defensins and cathelicidins in lung immunity. Innate Immun. 16:151-159.

Thompson, R. C., and K. Ohlsson. 1986. Isolation, properties, and complete amino acid sequence of human secretory leukocyte protease inhibitor, a potent inhibitor of leukocyte elastase. Proc. Natl. Acad. Sci. USA 83:6692-6696.

Turk, R., C. Piras, M. Kovacic, M. Samardzija, H. Ahmed, M. De Canio, A. Urbani, Z. F. Mestric, A. Soggiu, L. Bonizzi, and P. Roncada. 2012. Proteomics of inflammatory and oxidative stress response in cows with subclinical and clinical mastitis. J. Proteomics $75: 4412-4428$.

Wisniewski, J. R., A. Zougman, N. Nagaraj, and M. Mann. 2009. Universal sample preparation method for proteome analysis. Nat. Methods 6:359-362.

Yang, Y. X., X. X. Zhao, and Y. Zhang. 2009. Proteomic analysis of mammary tissues from healthy cows and clinical mastitic cows for identification of disease-related proteins. Vet. Res. Commun. $33: 295-303$. 